\title{
Relative Growth and Water Use of Seedlings from Three Italian Quercus Species
}

\author{
Daniel K. Struve, Francesco Ferrini, Alessio Fini, and Laura Pennati
}

\begin{abstract}
A species' water use characteristics and growth habits are important to urban foresters. Seedlings from three species (and two sources)—Quercus cerris L., Q. pubescens Willd., and Q. robur L.- -were container-grown and subjected to a three day water use trial under nonlimiting soil moisture conditions. Water use varied among species and between sources within a species. Larger seedlings used more water than smaller seedlings; $Q$. robur seedlings were the tallest, $70.5 \mathrm{~cm}(27.8 \mathrm{in})$, and had the greatest water

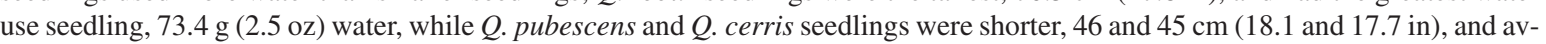
eraged 47.5 and $44.9 \mathrm{~g}$ (1.68 and $1.58 \mathrm{oz}$ ) water, respectively. Quercus pubescens seedlings had the highest water use $\mathrm{cm}^{-2}$ leaf area $(0.111 \mathrm{~g})$; $Q$. cerris seedlings had the highest height-adjusted water use $\left(1.4 \mathrm{~g}\right.$ water $\mathrm{cm}^{-1}$ height). There were significant differences in water use between sources within species. Principal component analysis, using 20 variables, showed that seedlings of $Q$. robur and $Q$. pubescens sources clustered while seedlings of the two $Q$. cerris sources were separate from each other and the $Q$. robur and $Q$. pubescens sources. The clustering reflected the proportionally greater distribution of dry weight to shoot growth and correspondingly less to root growth of the $Q$. robur and $Q$. pubescens seedlings, than that for $Q$. cerris seedlings. The results are related to the species' relative value to nursery producers and to the potential value to urban forest managers and the potential for cultivar development. Key Words. Drought Resistance; Dry Weight Partitioning; Seedling Growth; Water Use.
\end{abstract}

The urban environment is stressful. Tree growth and survival are limited by edaphic factors such as soil moisture, essential mineral nutrients, high $\mathrm{pH}$ and compaction, temperature extremes, light, airborne pollution, and mechanical injury (Fini and Ferrini 2007). A species' growth rate, drought resistance, and water use are important characteristics to urban forest managers. Oaks are adapted to various sites (from wet and humid floodplains to mesic uplands and xeric forests (Johnson et al. 2002) and thus are potential candidates for planting in the urban forest. Oaks (Quercus sp.) as a species are generally considered drought resistant (Abrams 1990), with drought resistance being conferred by a combination of drought avoidance and tolerance mechanisms (Abrams 1990). Three common Italian oak speciesQuercus cerris L., Q. robur L., and Q. pubescens (Willd.)-are the subject of this study. Quercus robur has the greatest potential size, followed by $Q$. cerris and $Q$. pubescens (Krussman 1986).

In European forests, the genetic complex of Quercus robur, $Q$. petraea, and $Q$. pubescens occupy a continuum of mesic-toxeric sites with $Q$. cerris occupying more xeric sites. The authors are unaware of any study that compares the relative drought resistance among these three species. However, $Q$. robur is considered the least and $Q$. pubescens the most drought resistant species (Fineschi et al. 2002). Quercus pubescens drought resistance is attributed to both drought avoidance and tolerance mechanisms. Under drought conditions, Quercus pubescens trees express drought avoidance traits such as: maintenance of hydraulic conductivity and high relative leaf moisture content, high assimilation rates and stomatal conductance, and low water use efficiency, attributed to a deep root system that allows access to subsurface soil moisture (Damesin and Rambal 1995; Damesin et al. 1997; Damesin et al. 1998; Nardini et al. 1998; Nardini and Pitt 1999; Lo Gullo et al. 2003; Mediavilla and Escudero 2004; Fotelli et al. 2005; Poyatos et al. 2005; Zweifel et al. 2005; Zweifel et al. 2006). Under extreme drought, $Q$. pubescens trees close their stomata as predawn leaf moisture potentials decrease (Damesin and Rambal 1995; Tognetti et al. 1999), and can shed leaves and limit the current season's shoot growth to avoid desiccation (Nardini and Pitt 1999; Lo Gullo et al. 2003). Quercus pubescens also expresses drought tolerance by a rapidly increasing its leaf water potential and leaf conductance following drought relief (Tognetti et al. 1999; Galle et al. 2007). Quercus robur and $Q$. petraea also respond to drought using both drought avoidance and tolerance mechanisms. However, because of higher water use efficiency, $Q$. petraea seedlings are considered better adapted to xeric sites (Epron and Dreyer 1993). Under nonlimiting soil moisture conditions, $Q$. robur seedlings have a faster growth rate, but under drought they have lower rates of assimilation and stomatal conductance than $Q$. petraea seedlings (Steudle and Meshcheryakov 1996; Ponton et al. 2002; Gieger and Thomas 2005). Although $Q$. robur seedlings are not as drought resistant as $Q$. petraea seedlings, their quicker recovery from drought was considered an expression of greater drought tolerance.

Less studied is $Q$. cerris' physiological response to drought. It is considered a mesophile species (D'Alessandro et al. 2006). It expressed less stomatal control than the xeric-adapted Fraxinus ornus during a summer drought indicative of deep root access to subsurface soil moisture (D'Alessandro et al. 2006). One study compared $Q$. cerris and $Q$. pubescens seasonal water use (Valentini et al. 1992). Both species relied on ground water (as opposed to surface soil moisture) during a summer drought, with $Q$. pubescens being more water conserving than $Q$. cerris. Another study compared $Q$. petraea and Q. cerris sap flow and cavitation. Quer- 
cus cerris trees had higher sap flow than $Q$. petraea in part due to higher water storage (Tognetti et al. 1996). Both species experienced progressive drought stress during the day, but recovered by night, demonstrating high degree of drought tolerance. Based on seasonal reductions in root hydraulic conductance relative to leaf area, leaf water potential, and leaf relative water content, $Q$. cerris was considered a drought tolerant species (Nardini et al. 1999).

No studies have compared the relative growth and drought resistance of $Q$. cerris, $Q$. pubescens and $Q$. robur, which is understandable as they are not sympatric species. However, in urban landscapes, these species are all candidates for planting and thus the relative growth rates and water use characteristics are concerns to both nursery producers and urban forest managers as they could be sympatric species in the context of the urban forest.

Oaks are genetically diverse. Quercus robur, Q. petraea, and $Q$. pubescens form a genetic complex (Bruschi et al. 2000) characterized by high genetic diversity (Dumolin-Lapegue et al. 1999; Kleinschmit 1993; Petit et al. 2002). Morphological characteristics of fruits, leaves, and twigs indicated that $Q$. robur and $Q$. pubescens are divergent species, while $Q$. petraea and $Q$. pubescens form a continuum of intermediate types (Dupouey and Badeau 1993). In contrast, genetic analysis indicated that Quercus robur and $Q$. petraea are less differentiated from each other than they are from $Q$. pubescens (Dumolin-Lepegue 1999). Genetic diversity is greater among individuals in mixed stands than among individuals from pure stands (Dumolin-Lepegue 1999). Recent hybridization and introgression maintain the high degree of genetic diversity found within these species (Dumolin-Lepegue 1999; Bruschi et. al. 2000). Italy served as one refugium during the glaciation of Northern Europe (Kremer et al. 2002; Petit et al. 2002). Genetic analysis indicates that current Italian oak populations originated in Sicilian and Balkan refugia (Fineschi et al. 2002). Genetic analysis showed that Quercus cerris and $Q$. suber are clearly divergent from the other sections of the white oak complex (Petit el al., 2002; Curtu et al. 2004).

This study was conducted to determine the inter- and intraspecies variation in the growth rate, dry weight partitioning, and water use of seedlings from two sources from each of three Italian oak species in order to assess the relative fitness for nursery production, and survival and growth in the urban forest.

\section{MATERIALS AND METHODS}

Acorns were collected in fall 2006 from two sources from each of three species (Table 1) and sown the following February in $0.9 \mathrm{~L}$ ( $0.23 \mathrm{gal}), 12 \mathrm{~cm}$ (4.7 in) tall, square black plastic containers. In March, acorns were sown one per container in a 3:1 (by vol) peatmoss:pumice substrate supplemented with $3 \mathrm{~kg} \mathrm{~m}^{-3}$ $\left(4.9 \mathrm{lb} \mathrm{yd}^{-3}\right) 15 \mathrm{~N}-2.9 \mathrm{P}-\mathrm{K} 7.12$ controlled release fertilizer (15-712 eight to nine month release, Osmocote, Scotts Miracle-Gro, Marysville, $\mathrm{OH}$ ). The seedlings were spaced container-to-container and grown under $40 \%$ neutral shade cloth (black woven polypropylene fabric, Boscato Reti, Vicenza, Italy) at the University of Florence's Polo Scientifico campus, Sesto Fiorentino. In July, they were repotted into $2.1 \mathrm{~L}$ (0.55 gal) containers [18 cm tall, $10 \mathrm{~cm}$ square (7.1 and 3.9 in, respectively) black plastic] filled with the same substrate as before. They were spaced container-to-container and returned to the shade house.

In September, 40 seedlings were randomly selected from each of the six sources-a total of 240 seedlings. The seedlings were moved to a glasshouse under $50 \%$ neutral shade. The plants were spaced at twice the container diameter in a randomized complete block design with one replication on each of two greenhouse benches.

Air temperature, relative humidity and photosynthetically active radiation (PAR, 400 to $700 \mathrm{~nm}$ ) were recorded every half hour using air temperature and relative humidity HD 9008TR (Delta Ohm, Padova, Italy) and PAR sensor LP PAR01, with sensors placed at mid-canopy height.

Daily water use was calculated by first watering the substrate to capacity, allowing the substrate to drain for one hour and weighting the individual seedling-substrate-container units. The seedlings were re-weighed approximately 24 hours later. The seedlings were then re-watered and the weighing schedule repeated for the following two days. The differences in daily weights were attributed to transpiration. The daily differences in weights were averaged to derive the average daily water use values for individual seedling during the three-day water use period.

At the end of the three-day water use period, all but four seedlings from each source (these seedlings were used in another study) were destructively harvested and the following data collected: plant height $(\mathrm{cm})$, leaf number and area $\left(\mathrm{cm}^{2}\right)$, and leaf, stem, and fine and coarse (root diameters of $<2$ and $\geq 2 \mathrm{~mm}$, respec-

Table. 1. Description of Quercus species used in the experiment.

\begin{tabular}{|c|c|c|c|}
\hline Species & Source No. & Provenance & Description \\
\hline \multirow[t]{2}{*}{ Q. cerris } & 1 & Vivai Gubbio, Pupaggi di Sellano & $\begin{array}{l}\text { bulked seed lot collected from selected mother trees in single-species stands and pur- } \\
\text { chased from a commercial forestry nursery Latitude } 42^{\circ} 53^{\prime} 25^{\prime \prime} .36 \mathrm{~N} \text {; Longitude } \\
12^{\circ} 55^{\prime} 43^{\prime \prime} 51 \mathrm{E} \text {; elevation: } 547 \mathrm{~m}(1,777 \mathrm{ft}) \text {. }\end{array}$ \\
\hline & 2 & Vivaio Camaldoli, zona Cerreta & $\begin{array}{l}\text { bulked seed lot collected from selected mother trees in single-species stands and pur- } \\
\text { chased from a commercial forestry nursery Cerreta Latitude } 43^{\circ} 49^{\prime} 23^{\prime \prime} .55 \mathrm{~N} \text {; Longitude } \\
11^{\circ} 49^{\prime} 09^{\prime \prime} 07 \mathrm{E} \text {; elevation: } 500 \mathrm{~m}(1,625 \mathrm{ft})\end{array}$ \\
\hline \multirow[t]{2}{*}{$Q \cdot$ pubescens } & 5 & Vivaio Gubbio, Bazzano Inferiore & $\begin{array}{l}\text { bulked seed lot collected from selected mother trees in mixed-species stands and pur- } \\
\text { chased from a commercial forestry nursery Bazzano Latitude } 42^{\circ} 46^{\prime} 45^{\prime} .71 \mathrm{~N} \text {; Longitude } \\
12^{\circ} 47^{\prime} 08.41 \mathrm{E} \text {; elevation: } 384 \mathrm{~m}(1,248 \mathrm{ft})\end{array}$ \\
\hline & 6 & Vivaio Camaldoli, zona Cerreta & $\begin{array}{l}\text { bulked seed lot collected from selected mother trees in mixed-species stands and pur- } \\
\text { chased from a commercial forestry nursery Amiata Latitude } 42^{\circ} 54^{\prime} 00^{\prime \prime} .00 \mathrm{~N} \text {; Longitude } \\
11^{\circ} 37^{\prime} 48 \mathrm{E} \text {; elevation: } 604 \mathrm{~m}(1963 \mathrm{ft})\end{array}$ \\
\hline \multirow[t]{2}{*}{ Q. robur } & 7 & Vivaio Gubbio, Pineta St. Vitale & $\begin{array}{l}\text { bulked seed lot collected from selected mother trees in mixed-species stands and pur- } \\
\text { chased from a commercial forestry nursery Pineta Latitude } 44^{\circ} 29^{\prime} 38^{\prime \prime} .62 \mathrm{~N} \text {; Longitude } \\
12^{\circ} 16^{\prime} 43^{\prime \prime} 80 \mathrm{E} \text {; elevation: } 3 \mathrm{~m}(10 \mathrm{ft}) \text {. }\end{array}$ \\
\hline & 8 & Parco cascine, Firenze & $\begin{array}{l}\text { seed collected from a single tree in urban park surrounded by } Q . \text { robur trees Cascine } \\
\text { Latitude } 43^{\circ} 47^{\prime} 07^{\prime} .61 \text {; N Longitude } 11^{\circ} 12^{\prime} 50^{\prime} 39 \mathrm{E} \text {; elevation: } 47 \mathrm{~m}(153 \mathrm{ft})\end{array}$ \\
\hline
\end{tabular}


tively) root dry weights (g). Leaf area and number were estimated by scanning a subsample of the leaves (Mustek Scan Express A3 USB) and with image analysis software (Image Tool, U. of Texas Health Services Center, San Antonio, TX), also using the proportion of the subsample weight-to-total leaf weight to estimate total leaf number and area. From this data, the following variables were calculated: total shoot dry weight (leaves + shoot dry weights), total root dry weight (fine + coarse root dry weight), total plant dry weight (total shoot + total root dry weight), percent of total plant dry weight in leaves, roots, stems, fine and coarse roots, shootto-root dry weight ratio (total shoot dry weight/total root dry weight), water transpiring-to-absorbing ratio [leaf surface area/ fine root dry weight $\left.\left(\mathrm{cm}^{2} \mathrm{~g}^{-1}\right)\right]$, specific leaf weight $\left(\mathrm{cm}^{2} \mathrm{~g}^{-1}\right)$ and average height adjusted water use $\left(\mathrm{g} \mathrm{cm}^{-2}\right.$ seedling height day-1).

Data were subject to multivariate analysis of variance using the general linear model procedure (SPSS, Version 12.0) as a fixed effects model with two replications with 20 seedlings per replication and seed source. Means were separated using the StudentNeuman-Kuels test at the $\alpha \leq 0.05$ level of significance. The data were also subjected to principal component analysis (SPSS, Version 12.0 ) by seed source using the 20 variables described above.

\section{RESULTS AND DISCUSSION}

Substrate bulk density averaged $0.43 \mathrm{~g} \mathrm{~cm}^{-3}$ (Table 2). The substrate had $63.7 \%$ total pore space and $46.8 \%$ water-filled pore space at field capacity (Table 2 ). The $2.1 \mathrm{~L}$ substrate volume contained an estimated $0.98 \pm 0.04 \mathrm{~L}(0.25 \mathrm{gal} \pm 0.01)$ of water. Maximum water loss in any one day during the three day trial was $<0.145 \mathrm{~L}(0.04 \mathrm{gal})$, thus, the plants were not under substrate moisture stress during the three day water use period. Average PAR between sunrise and sunset ranged from 160 to $180 \mu$ moles $\mathrm{m}^{-2} \mathrm{~s}^{-1}$; daily average relative humidity ranged from $47 \%$ to $51 \%$ and average daily temperature ranged from 19 to $21^{\circ} \mathrm{C}\left(67\right.$ to $\left.70^{\circ} \mathrm{F}\right)$. The greenhouse was cooled by convection through a combination of side wall and roof vents.

Table 2. Physical properties of the 3:1 peatmoss:pumice (by vol) substrate in $18 \mathrm{~cm}$ tall, $2.1 \mathrm{~L}$ volume container.

\begin{tabular}{lcc}
\hline Variable & Mean & $\begin{array}{l}\text { Standard } \\
\text { deviation }\end{array}$ \\
\hline Bulk density $\left(\mathrm{g} \mathrm{cm}^{-3}\right)$ & $0.43^{z}$ & 0.05 \\
Total pore space $(\%)$ & 63.7 & 2.3 \\
Water-filled pore space & 46.8 & 2.0 \\
Air-filled pore space & 16.5 & 4.2 \\
\hline
\end{tabular}

${ }^{\mathrm{z}}$ Each value is the mean of five containers.

\section{Water Use}

Seedlings of Quercus robur were the tallest and had the greatest water use per seedling, but had lower height-adjusted water use than $Q$. cerris sources (Table 3). However, water use per $\mathrm{cm}^{2}$ leaf surface was lower than $Q$. pubescens sources. Within each species, there were differences between the sources in seedling height, water use per $\mathrm{cm}^{2}$ leaf area and height-adjusted water use, except between the $Q$. robur sources for water use per seedling and between the $Q$. cerris sources for height-adjusted water use (Table 4). Among all the sources, water use per seedling varied by almost $200 \%$ (Q. cerris Amiata and Q. pubescens Cerreta sources versus both $Q$. robur sources, 36.0 and $32.6 \mathrm{~g}$ versus 72.1 and $74.7 \mathrm{~g}$ seedling $^{-1} \mathrm{day}^{-1}$, respectively) (Table 4). The $Q$. robur Cascine source had lower water use per $\mathrm{cm}^{2}$ leaf area than the Pineta source, which was higher than the $Q$. cerris Sellano source, and similar to the Amiata source, and lower than both $Q$. pubescens sources (Table 4). Height-adjusted water use varied by $80 \%$ among all the sources $[Q$. robur Cascine versus $Q$. pubescens Cerreta (1.2 versus $1.5 \mathrm{~g} \mathrm{~cm}^{-2}$ height day $\left.{ }^{1}\right)$ ]. Thus, the basis for the differences in water use among the sources was complex. Some of the differences in water use per seedling can be attributed to differences in seedling size; larger seedlings, relative to shorter seedlings, tended to have greater leaf area and greater water use per seedling (Figure 1). However, the correlations between seedling height and water use per seedling were low; $\mathrm{R}^{2}$ values for individual sources were $<0.05$, except for the $Q$. pubescens Cerreta source where it was 0.21 . Also, there were low correlations between water use per seedling and heightadjusted water use (Figure 2). The relationship between heightadjusted water use and seedling height of the six seed sources used in this study was markedly different from that of six Eastern North American Quercus species. For the Eastern North American species, when the individual seedling heights within a 1/2-sib family were plotted against height-adjusted water use, a graph similar to an exponential decay curve was seen (Struve et al. 2006). No such pattern was seen within the Italian seed sources.

As a summary example, the seedlings in the tallest source, Q. robur Cascine, used the highest water seedling ${ }^{-1}$, but had the lowest water use per $\mathrm{cm}^{2}$ leaf area and the lowest height-adjusted water use. In contrast, the seedlings in the shortest source, $Q$. pubescens Cerreta, used the least water per seedling, but had the greatest water use per $\mathrm{cm}^{2}$ leaf area and the highest heightadjusted water use. Further, Figures 1 and 2 reveal significant within source variation in water use characteristics. Thus, basing a species' water use characteristics on a single water use parameter or on a single seed source can be misleading. The great variation in water use characteristics between species, sources and within sources presents an opportunity for genetic improve-

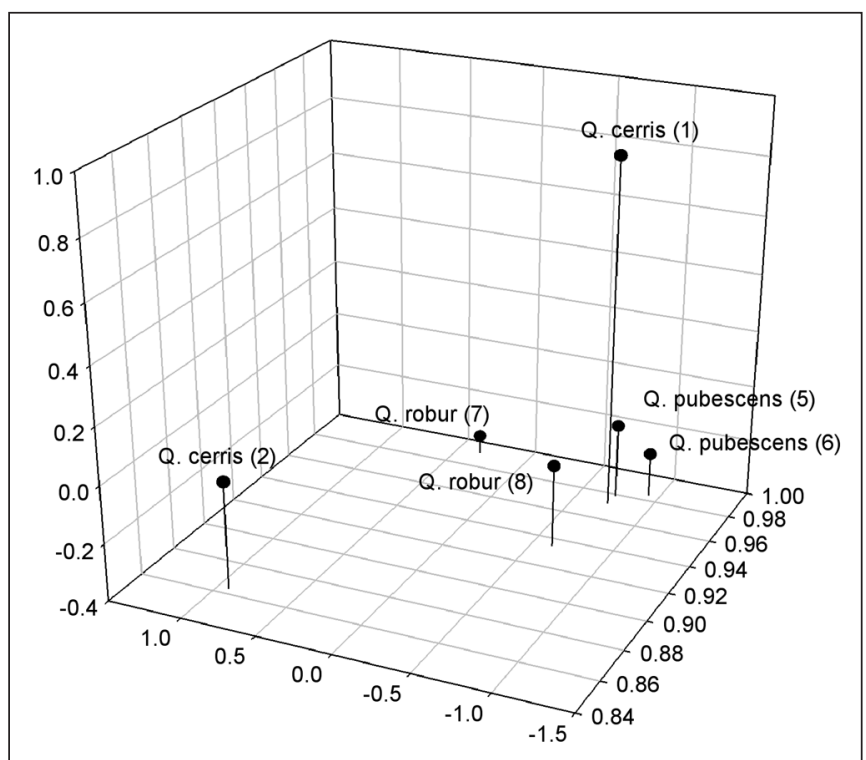

Figure 1.The relationship among seed sources, two sources from each of three Quercus species (cerris, pubescens, and robur). Total shoot length, total plant dry weights and leaf area-to-fine root dry weight were plotted against the first, second and third (respectively) principal component axes. The numbers in parenthesis refer to the seed source numbers in Table 1. 
Table 3. Water use of three Quercus species over three days under greenhouse conditions.

\begin{tabular}{llllc}
\hline & & \multicolumn{3}{c}{ Average daily water use $\left(\mathrm{g} \mathrm{day}^{-1}\right)$} \\
\cline { 3 - 5 } Species & Height $(\mathrm{cm})$ & seedling-1 & $\begin{array}{l}\text { leaf area } \\
(\mathrm{cm}-2)\end{array}$ & $\begin{array}{c}\text { Height-adjusted } \\
(\mathrm{cm}-1)^{\mathrm{z}}\end{array}$ \\
\hline Q. cerris & $45.3 \mathrm{~A}^{\mathrm{y}}$ & $47.5 \mathrm{~A}$ & $0.091 \mathrm{~A}$ & $1.4 \mathrm{~B}$ \\
Q. pubescens & $46.0 \mathrm{~A}$ & $44.9 \mathrm{~A}$ & $0.111 \mathrm{~B}$ & $1.3 \mathrm{~A}$ \\
Q. robur & $70.5 \mathrm{~B}$ & $73.4 \mathrm{~B}$ & $0.084 \mathrm{~A}$ & $1.3 \mathrm{~A}$ \\
\hline
\end{tabular}

$\mathrm{z}$ Height-adjusted water use was calculated by dividing the average daily water use by seedling height.

Means within a column followed by different letters are significantly different from each other at the $\alpha=0.05$ level using the Student-Neuman-Kuels test. Each value is the mean of 72 plants.

Table 4. Water use of two sources from three Quercus species over three days under greenhouse conditions.

\begin{tabular}{|c|c|c|c|c|c|}
\hline \multirow[b]{2}{*}{ Species } & \multirow[b]{2}{*}{ Source } & \multirow[b]{2}{*}{ Height $(\mathrm{cm})$} & \multicolumn{3}{|c|}{ Average dailywater use (g day-1) } \\
\hline & & & seedling $^{-1}$ & $\begin{array}{l}\text { leaf } \\
\text { area } \\
\left(\mathrm{cm}^{-2}\right)\end{array}$ & $\begin{array}{l}\text { Height- } \\
\text { adjusted } \\
\left(\mathrm{cm}^{-1}\right)^{2}\end{array}$ \\
\hline \multirow[t]{2}{*}{ Q. cerris } & Sellano & $54.2 \mathrm{C}^{\mathrm{y}}$ & $58.9 \mathrm{~B}$ & $0.087 \mathrm{~B}$ & $1.4 \mathrm{~B}$ \\
\hline & Amiata & $36.3 \mathrm{AB}$ & $36.0 \mathrm{~A}$ & $0.094 \mathrm{C}$ & $1.3 \mathrm{AB}$ \\
\hline \multirow[t]{2}{*}{ Q. pubescens } & Bazzano & $62.2 \mathrm{D}$ & $57.2 \mathrm{~B}$ & $0.104 \mathrm{D}$ & $1.2 \mathrm{~A}$ \\
\hline & Cerreta & $29.7 \mathrm{~A}$ & $32.6 \mathrm{~A}$ & $0.118 \mathrm{E}$ & $1.5 \mathrm{BC}$ \\
\hline \multirow[t]{2}{*}{ Q. robur } & Pineta & $67.1 \mathrm{D}$ & $72.1 \mathrm{C}$ & $0.098 \mathrm{CD}$ & $1.4 \mathrm{~B}$ \\
\hline & Cascine & $73.9 \mathrm{E}$ & 74.7C & $0.070 \mathrm{~A}$ & $1.2 \mathrm{~A}$ \\
\hline
\end{tabular}

${ }^{\mathrm{z}}$ Height-adjusted water use was calculated by dividing the average daily water use by seedling height.

y Means within a column followed by different letters are significantly different from each other at the $\alpha=0.05$ level using the Student-Neuman-Kuels test.

Each value is the mean of 36 plants.

ment through sexual or asexual methods. For instance, tall seedlings with either high or low height-adjusted water use could be identified within each seed source. Undetermined is whether the differences in an individual seedling's height-adjusted water use are related to adaptive features such as drought resistance, that would confer increased fitness to the urban forest environment.

\section{Growth}

For the two $Q$. cerris sources, three components in a principal component analysis that used 20 variables, extracted $79 \%$ and $74 \%$ (sources 1 and 2, respectively) of the total variation. Three components extracted $80 \%$ and $77 \%$ (sources 5 and 6 ) and $83 \%$ and $79 \%$ (sources 7 and 8) of the total variation for $Q$. pubescens and Q. robur sources, respectively. In the first component, factors associated with aboveground growth and dry weight (height, leaf number and area, total shoot dry weight, and shoot-root dry weight ratio) were highly correlated (> 0.80) and loaded positively on the first principal component axis, while root system associated factors (percent of root dry weight and percent coarse root dry weight) and water use $\mathrm{cm}^{-2}$ leaf surface area, loaded negatively. In the second component, rootassociated variables such as total, fine, and coarse root dry weight loaded positively while shoot factors as shoot-to-root dry weight ratio and percent shoot dry loaded negatively. In the third component, percent leaf area and leaf area-to-fine root dry weight ratio loaded positively while percent fine root and total shoot dry weight loaded negatively. Plotting total shoot length, total plant dry weight, and leaf area-to-fine root dry weight on the first, second, and third component axes, respectively, showed that sources $5,6,7$, and $8(Q$. pubes-
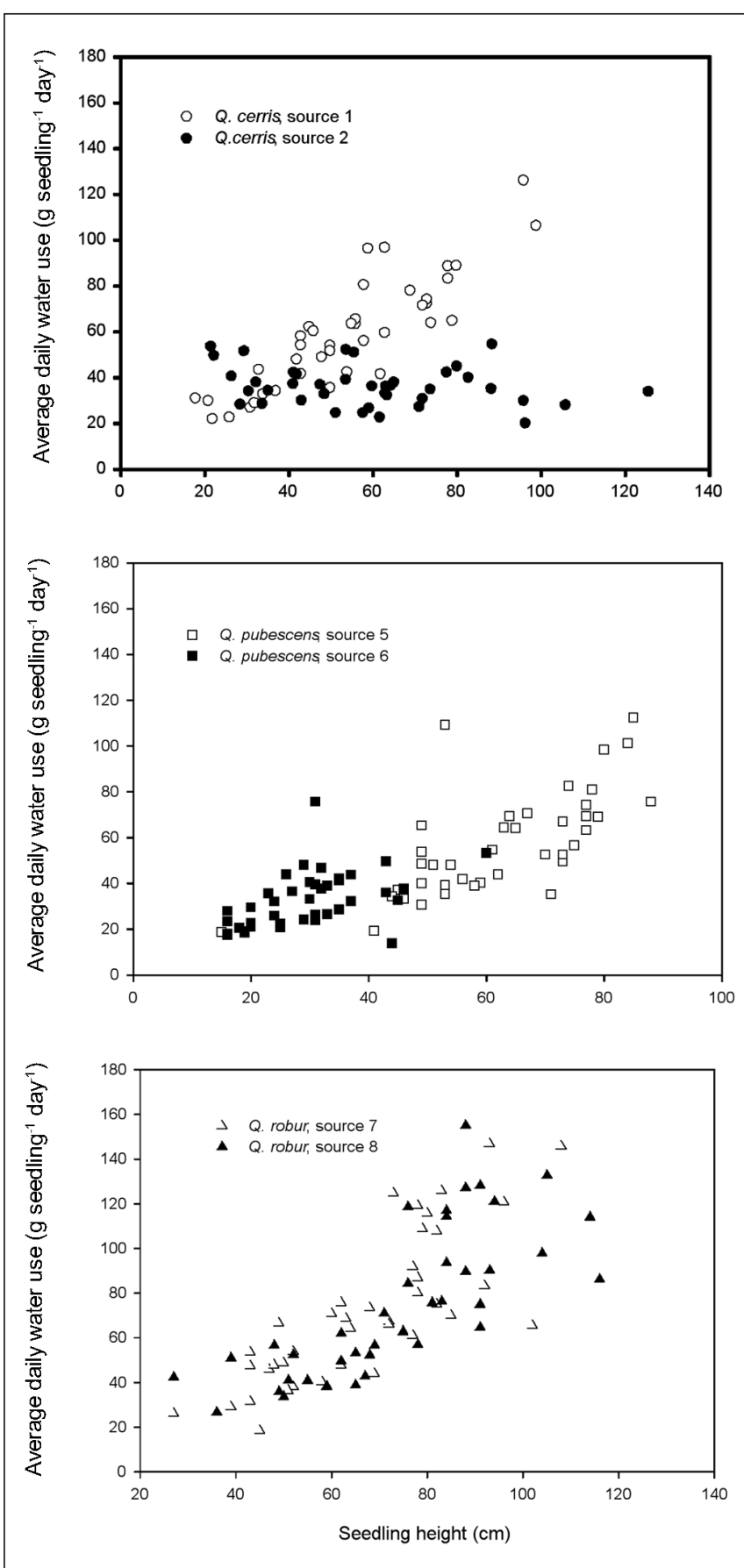

Figure 2. Water use per seedlings plotted against seedling height for two sources from each of three Quercus species.

cens and $Q$. robur) clustered together while the two $Q$. cerris sources were separated from each other and the other species (Figure 3).

Quercus robur seedlings had greater leaf number and leaf area, greater leaf, stem and total plant dry weights and a larger shootto-root dry weight ratio than $Q$. cerris and $Q$. pubescens seedlings (Table 5). Quercus robur seedlings had similar coarse and total root dry weights as $Q$. pubescens seedlings, which was lower than that for $Q$. cerris seedlings. Quercus robur seedlings had greater specific leaf area than $Q$. pubescens seedlings, but lower than $Q$. cerris seedlings. As with the seedling height and water use data, 


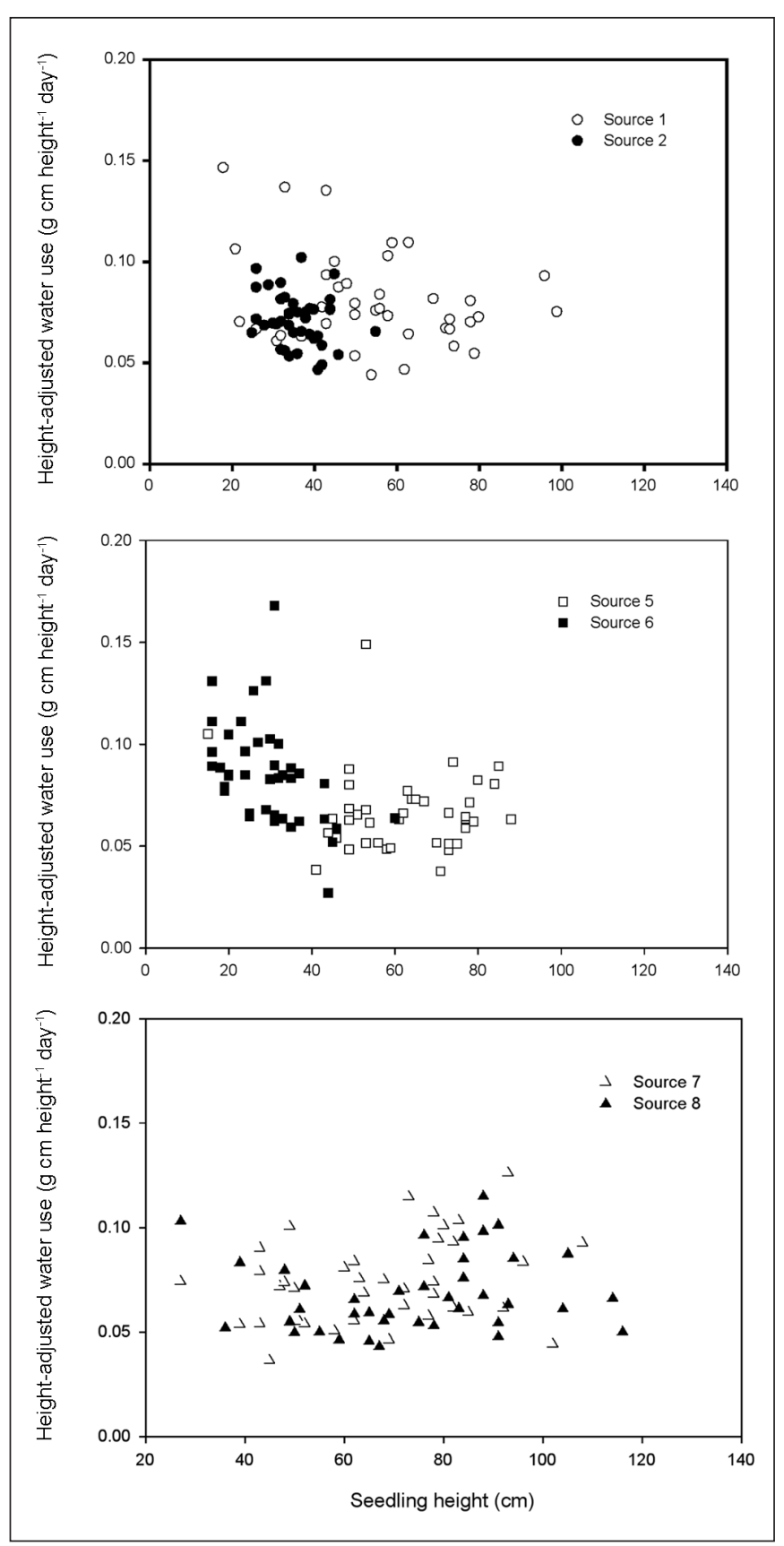

Figure 3. Height-adjusted water use (g water per $\mathrm{cm}$ seedling height per day) for two sources from each of three Quercus species.

there were significant differences between the sources within a species (Table 6). The extremes among the sources were Quercus robur seedlings from the Cascine source which had the greatest leaf area and dry weights, except for coarse and total root dry weights which were greatest in seedlings from the $Q$. cerris Amiata source.

Quercus robur seedlings had a similar percentage of total plant weight in leaf tissue as $Q$. pubescens seedlings, but the highest percentage of total plant dry weight in stem tissue, the greatest leaf area-to-fine root dry weight ratio and the lowest percentage of total plant dry weight in total, fine and coarse root dry weights (Table 7). Quercus cerris seedlings had the greatest percentage of total plant dry weight in total root, fine, and coarse root dry weights and the greatest leaf area ratio (Table 7). There were significant differences among the sources in percentage of total plant dry weight in leaves, stems and root tissue, leaf areato-fine root dry weight ratio and leaf area ratio (Table 8). One of the most sticking differences among the sources was the range in the leaf area-to-fine root (the water transpiring-to-water absorbing) ratios. The greatest difference among the sources exceeded $250 \%, 321.3$ versus $128.3 \mathrm{~cm}^{2} \mathrm{~g}^{-1}$, for the $Q$. robur Cascine versus $Q$. cerris Amiata, respectively. Almost as great was the difference in the leaf area-to-fine root dry weight ratio between the two $Q$. cerris sources, 340.5 versus $128.3 \mathrm{~cm}^{2} \mathrm{~g}^{-1}$, a $265 \%$ difference. It is not known whether these differences reflect differences in root system water absorbing efficiency or in leaf water use efficiency.

Quercus robur seedlings had a resource allocation pattern of a species capable of rapid growth: a greater investment in aboveground biomass at the expense of belowground biomass: more leaves of smaller size, a greater percentage of plant dry weight in stem and leaf tissues and larger shoot-to-root ratio. As a consequence of the relatively high investment in aboveground biomass, it had the greatest water use per seedling, but had the compensating adaptive traits of relatively lower water use $\mathrm{cm}^{-2}$ leaf area and high leaf area-to-fine root dry weight ratio. Quercus pubescens seedlings, relative to $Q$. robur seedlings, had a lower investment in aboveground biomass and a relatively greater investment in root tissue. They also had the highest water use per leaf area and lowest leaf area-to-fine root dry weight ratio. Quercus cerris seedlings had a higher investment root biomass than $Q$. pubecscens and $Q$. robur seedlings. However, there were significant differences among the sources in their growth habits and water use characteristics; the Bazzano, Cerreta, Cascine and Pineta $(Q$. pubescens and $Q$. robur, respectively) had similar growth and water use characteristics while the Sellano and Amiata (Q. cerris) sources had different growth habits and water use characteristics from each other and the other seed sources. Additionally, there were significant differences in height and water use characteristics. The results illustrate the remarkable degree of variation between and within these seed sources and the great potential for genetic improvement to address a changing world climate and the harsh environmental conditions associated with urban forests. The great degree of variation occurred whether the seeds were collected from an individual tree $(Q$. robur Cascine), mixed-species stands (both $Q$. pubescens sources) or single-species stands (both $Q$. cerris sources).

From a nursery production aspect, where crop value is determined by the rate of height and caliper growth, $Q$. robur is the most desired species, but the species with the highest water use per seedling. The $Q$. pubescens Bazzano source is a possible alternative to the two $Q$. robur sources. Those seedlings grew nearly as tall, but the seedlings of this source used $30 \%$ less water per seedling than the Cascine seedlings. The Bazzano source seedlings also had a more efficient root system than the Cascine seedlings absorbing 0.00038 and $0.00017 \mathrm{~g}$ water day ${ }^{-1} \mathrm{~g}^{-1}$ fine root dry weight, respectively. Seedlings of the $Q$. pubescens Cerreta source had the most efficient root system, $0.00065 \mathrm{~g}$ water per day per $g$ fine root dry weight. As a species, $Q$. pubescens can maintain high rates of hydraulic conductance during drought which was attributed to a deep rooting habit (Naraini et al. 1998; Nardini and Pitt 1999; Lo Gullo et al. 2003; Poyatos et al. 2005; Zweifel et al. 2006). The apparent water absorbing efficiency of 
Table 5. Leaf number and area and dry weights of plants from three Quercus species.

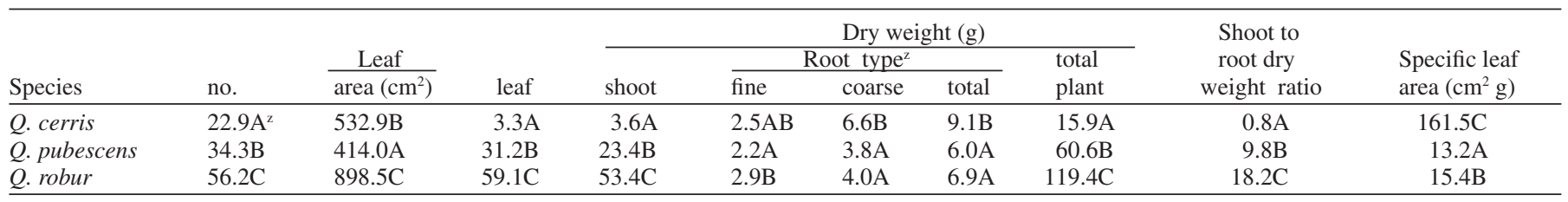

Means within a column followed by different letters are significantly different from each other at the $\alpha=0.05$ level using the Student-Neuman-Kuels test. Each value is the mean of 72 plants.

${ }^{\mathrm{z}}$ Fine roots were $<2 \mathrm{~mm}$ in diameter; coarse roots were $\geq 2 \mathrm{~mm}$ diameter.

Table 6. Leaf number and area and dry weights of plants from two Quercus sources from each of three species.

\begin{tabular}{|c|c|c|c|c|c|c|c|c|c|c|c|}
\hline \multirow[b]{3}{*}{ Species } & \multirow[b]{3}{*}{ Source } & \multirow[b]{3}{*}{ no. } & \multirow{3}{*}{$\frac{\text { Leaf }}{\text { area }\left(\mathrm{cm}^{2}\right)}$} & \multicolumn{5}{|c|}{ Dry weight (g) } & \multirow{3}{*}{$\begin{array}{l}\text { Total } \\
\text { plant }\end{array}$} & \multirow{3}{*}{$\begin{array}{l}\text { Shoot to } \\
\text { root dry } \\
\text { weight ratio }\end{array}$} & \multirow{3}{*}{$\begin{array}{l}\text { Specific leaf } \\
\text { area }\left(\mathrm{cm}^{2} \mathrm{~g}\right)\end{array}$} \\
\hline & & & & & & Root & $\mathrm{ype}^{2}$ & & & & \\
\hline & & & & leaf & shoot & fine & coarse & total & & & \\
\hline Q. cerris & Sellano & $28.9 \mathrm{AB}^{\mathrm{y}}$ & $680.9 \mathrm{BC}$ & $3.8 \mathrm{~A}$ & $4.1 \mathrm{~A}$ & $2.0 \mathrm{~A}$ & $5.1 \mathrm{~B}$ & $7.1 \mathrm{~A}$ & $15.0 \mathrm{~A}$ & $0.6 \mathrm{~A}$ & 179.2D \\
\hline \multirow[t]{2}{*}{ Q. pubescens } & Bazzano & $39.2 B$ & $552.4 \mathrm{~B}$ & $42.2 \mathrm{C}$ & $32.7 \mathrm{~B}$ & $2.3 \mathrm{AB}$ & $3.2 \mathrm{~A}$ & $5.5 \mathrm{~A}$ & $80.5 \mathrm{C}$ & $5.9 \mathrm{C}$ & $13.1 \mathrm{~A}$ \\
\hline & Cerreta & $9.3 \mathrm{AB}$ & $275.6 \mathrm{~A}$ & $20.5 \mathrm{~B}$ & $14.3 \mathrm{~A}$ & $2.1 \mathrm{~A}$ & $4.3 \mathrm{AB}$ & $6.4 \mathrm{~A}$ & $41.1 \mathrm{~B}$ & $2.2 \mathrm{~B}$ & $13.4 \mathrm{~A}$ \\
\hline \multirow[t]{2}{*}{ Q. robur } & Pineta & $32.7 \mathrm{AB}$ & $736.6 \mathrm{C}$ & $48.5 \mathrm{C}$ & $50.8 \mathrm{CB}$ & $2.6 \mathrm{BC}$ & $3.8 \mathrm{~A}$ & $6.4 \mathrm{~A}$ & 105.7D & $7.6 \mathrm{D}$ & $15.2 \mathrm{~B}$ \\
\hline & Cascine & $79.7 \mathrm{C}$ & $1060.4 \mathrm{D}$ & 69.7D & $60.8 \mathrm{C}$ & $3.3 \mathrm{C}$ & 4.1AB & $7.4 \mathrm{~A}$ & $133.0 \mathrm{E}$ & $9.4 \mathrm{E}$ & $15.2 \mathrm{~B}$ \\
\hline
\end{tabular}

${ }^{2}$ Fine roots were $<2 \mathrm{~mm}$ in diameter; coarse roots were $\geq 2 \mathrm{~mm}$ diameter.

${ }^{y}$ Means within a column followed by different letters are significantly different from each other at the $\alpha=0.05$ level using the Student-Neuman-Kuels test. Each value is the mean of 36 plants.

Table 7. Percentage of total plant dry weight in leaves, roots and stems, the leaf area-to-fine root dry weight sand leaf area ratios of seedlings from three Quercus species.

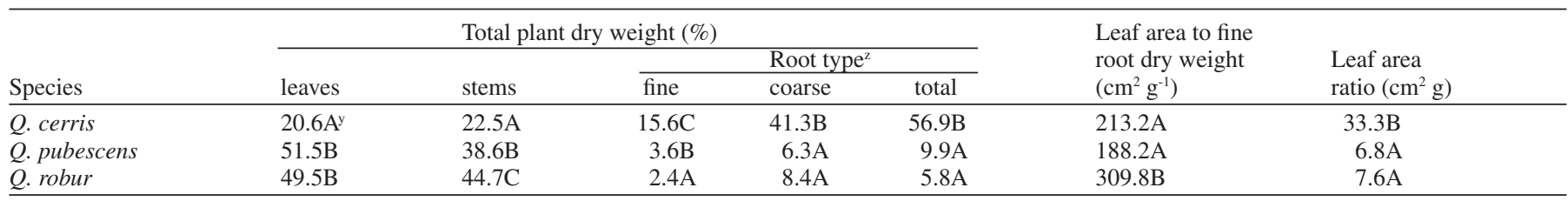

Means within a column followed by different letters are significantly different from each other at the $\alpha=0.05$ level using the Student-Neuman-Kuels test. Each value is the mean of 72 plants.

${ }^{\mathrm{z}}$ Fine roots were $<2 \mathrm{~mm}$ in diameter; coarse roots were $\geq 2 \mathrm{~mm}$ diameter.

Table 8. Percentage of total plant dry weight in leaves, roots and stems, the leaf area-to-fine root dry weight sand leaf area ratios of seedlings from two provenances of three Quercus species.

\begin{tabular}{|c|c|c|c|c|c|c|c|c|}
\hline \multirow[b]{3}{*}{$\underline{\text { Species }}$} & \multirow[b]{3}{*}{ Source } & \multirow[b]{3}{*}{ leaves } & \multicolumn{4}{|c|}{ Total plant dry weight (\%) } & \multirow{3}{*}{$\begin{array}{l}\text { Leaf area to fine } \\
\text { root dry weight } \\
\left(\mathrm{cm}^{2} \mathrm{~g}\right)\end{array}$} & \multirow{3}{*}{$\begin{array}{l}\text { Leaf area } \\
\text { ratio }\left(\mathrm{cm}^{2} \mathrm{~g}\right)\end{array}$} \\
\hline & & & & & Root t & & & \\
\hline & & & stems & total & fine & coarse & & \\
\hline \multirow[t]{2}{*}{ Q. cerris } & Sellano & $25.3 \mathrm{~B}^{\mathrm{y}}$ & $27.4 \mathrm{~B}$ & $47.3 \mathrm{~B}$ & $13.3 \mathrm{C}$ & $34.0 \mathrm{C}$ & $340.5 \mathrm{C}$ & $45.3 \mathrm{D}$ \\
\hline & Amiata & $16.0 \mathrm{~A}$ & $18.5 \mathrm{~A}$ & $65.5 \mathrm{C}$ & 17.9D & $47.6 \mathrm{D}$ & $128.3 \mathrm{AB}$ & $22.9 \mathrm{C}$ \\
\hline \multirow[t]{2}{*}{ Q. pubescens } & Bazzano & $52.5 \mathrm{D}$ & $40.7 \mathrm{D}$ & $6.8 \mathrm{~A}$ & $2.8 \mathrm{~A}$ & $4.0 \mathrm{~A}$ & $240.2 B$ & $6.9 \mathrm{~A}$ \\
\hline & Cerreta & $34.1 \mathrm{C}$ & $23.8 \mathrm{C}$ & $42.1 \mathrm{~B}$ & $34.9 \mathrm{~B}$ & $7.2 \mathrm{~B}$ & $13.1 \mathrm{~A}$ & $6.7 \mathrm{~A}$ \\
\hline \multirow[t]{2}{*}{ Q. robur } & Pineta & $45.8 \mathrm{C}$ & $48.1 \mathrm{E}$ & $6.1 \mathrm{~A}$ & $2.6 \mathrm{~A}$ & $3.5 \mathrm{~A}$ & $283.3 \mathrm{BC}$ & 7.2AB \\
\hline & Cascine & $50.5 \mathrm{D}$ & $44.2 \mathrm{D}$ & $5.4 \mathrm{~A}$ & $2.4 \mathrm{~A}$ & $3.0 \mathrm{~A}$ & $321.3 \mathrm{C}$ & $8.0 \mathrm{~B}$ \\
\hline
\end{tabular}

${ }^{\mathrm{z}}$ Fine roots were $<2 \mathrm{~mm}$ in diameter; coarse roots were $\geq 2 \mathrm{~mm}$ diameter.

${ }^{y}$ Means within a column followed by different letters are significantly different from each other at the $\alpha=0.05$ level using the Student-Neuman-Kuels test. Each value is the mean of 36 plants.

the root system, $\mathrm{g}$ water day $\mathrm{g}^{-1}$ fine root dry weight, was another contributing factor to maintenance of hydraulic conductivity. The Bazzano source seedlings had lower total plant dry weight than the Cascine seedlings, but part of the lower dry weight was attributed to lower leaf weight, which is not a factor in total plant dry weight after fall defoliation. Also, as a species, $Q$. pubescens is considered more drought resistant than $Q$. robur making it putatively better adapted to those urban environments where drought is the main constraint to growth and survival. Interestingly, the Bazzano source had similar dry weight distribution as the $Q$. robur seedling suggesting that it had a similar growth habitone that is associated with more rapid growth, a positive factor for nursery managers. Because of the relatively slower growth (the result of its greater biomass allocation to the root system) of the seedlings from the two $Q$. cerris sources, there is apparently no compelling reason for a nursery manager to produce $Q$. cerris 
plants for urban greening purposes. However, the Amiata source, the slowest growing source, had the second highest root system efficiency, $0.00060 \mathrm{~g}$ water $\mathrm{g}^{-1}$ fine root dry weight day ${ }^{-1}$ and the conservative growth habit of the Amiata and Cerreta sources are of interest to urban foresters. The findings of this study show the great variation between and within species in economically and physiologically important traits to the nursery producers and urban foresters. More studies are needed to find other potentially better adapted sources for nursery production and the urban forest environment in a rapidly changing world climate.

There was significant variation in growth and water use characteristics among the seedlings from the six seed sources (two seed source of each of three species) tested. Average seedling height differed by $229 \%$ among the seed sources. The Q. robur sources, and to a lessor degree the $Q$. cerris Sellano and the $Q$. pubescens Bazzano sources, had a resource allocation pattern of a species capable of rapid growth: a greater investment in aboveground biomass at the expense of belowground biomass. In part, because of greater seedling size, $Q$. robur Cascine seedlings used the most water seedling ${ }^{-1} \mathrm{day}^{-1}$, but had the lowest water use $\mathrm{cm}^{-2}$ leaf area and highest leaf area-to-fine root dry weight ratio. $Q$. pubescens seedlings had the highest water use $\mathrm{cm}^{-2}$ leaf area and seedlings of the $Q$. pubescens Cerreta source, which was the shortest source, had the highest height-adjusted water use ( $\mathrm{g}$ water day ${ }^{-1} \mathrm{~cm}^{-2}$ seedling height). There were low correlations between seedling height and height-adjusted water use, which would allow for the selection of any plant height and height-adjusted water use combination. Thus, seedlings with rapid growth and a conservative water use habit (fast growing seedling with low height-adjusted water use) could be selected. There is great variation between and within these three oak species in economically and ecologically important traits from which to select and develop individuals or populations better adapted to stressful urban forest sites and to a changing global climate. Additional studies, preferably conducted with clonal material, are needed to determine if the seedling growth and water use characteristics described here are also expressed in larger sized plants.

These species are not commonly available in North American nurseries. However, they may be candidates for North American urban forests. These Apennine seed sources are found on limestone-derived shallow soils (www.soilmaps.it/download/csibrochure se.a4.pdf). Thus, they have evolved in soil conditions not unlike those typical of the urban forests. The seed sources were collected from European Plant Hardiness Zones 8 to 9 [-12 to $-1^{\circ} \mathrm{C}\left(10\right.$ to $\left.30^{\circ} \mathrm{F}\right)$, www.uk.gardenweb.com/forums/zones/hxeleg.gif]. However, the species are found in colder climates [Zone 6 ; $\left(-23\right.$ to $-18^{\circ} \mathrm{C}$ or -10 to $\left.0^{\circ} \mathrm{F}\right)$; forest.jrc.it/forest_and_climate/ forest_trends/spdistribution]. There are specimens of Quercus cerris, $Q$. pubescens, and $Q$. robur at Dawes Arboretum, USDA Plant Hardiness Zone $5 \mathrm{~b} / 6 \mathrm{a}$, so the species' potential adaptive range is great. Further research is needed to determine the adaptive potential of these species to urban forests of North America.

\section{LITERATURE CITED}

Abrams, M.D. 1990. Adaption and responses to drought in Quercus species of North America. Tree Physiology 7:227-238.

Bruschi, P.G.G. Vendramin, F. Bussotti, and P. Grossoni. 2000. Morphological and molecular differentiation between $Q$. petraea (Matt.) Liebl. and Quercus pubescens Willd. (Fagaceae) in Northern and Central Italy. Annals of Botany 85:325-333.
Curtu, A.L., R. Finkeldey, and O. Gailing. 2004. Comparative sequencing of a microsatellite locus reveals size homoplasy within and between European oak species (Quercus spp.). Plant Molecular Biology 22:339-346.

D'Alessandro, A. Saracino, and M. Borghetti. 2006. Thinning affects water use efficiency of hardwood saplings naturally recruited in a Pinus radiata D. Don plantation. Forest Ecology and Management 222:116-122.

Damesin, C., and S. Rambal. 1995. Field study of leaf photosynthetic performance by a Mediterranean deciduous oak tree (Quercus pubescens) during a severe summer drought. New Phytologist 131:159-167.

Damesin, C., S. Rambal, and R. Joffre. 1997. Between-tree variations in leaf $\delta 13 \mathrm{C}$ of Quercus pubescens and Quercus ilex among Mediterranean habitats with different water availability. Oecologia 111:26-35.

Damesin, C., S. Rambal, and R. Joffre. 1998. Seasonal and annual changes in leaf $\delta 13 \mathrm{C}$ in two co-occuring Mediterranean oaks: relations to leaf growth and drought progression. Functional Ecology 12:778785

Dumolin, S, A. Kremer, and R.J. Petit. 1999. Are chloroplast and mitochondrial DNA variation species independent in oaks? Evolution 53(5):1406-1413.

Dupouey, L.L., and V. Badeau. 1993. Morphological variability of oaks [Quercus robur L, Quercus petraea (Matt) Liebl, Quercus pubescens Willd] in northeastern France: preliminary results. Annals of Forest Science 50, Suppl. 1. 35s-40s.

Epron, D., and E. Dreyer. 1993. Long-term effects of drought on photosynthesis of adult oak trees [Quercus petraea (Matt.) Liebl. and $Q$. robur L.] in a natural stand. New Phytologist 125:381-389.

Fineschi, S., D. Taurchini, P. Grossoni, R.J. Petit, and G.G. Vendramin. 2002. Chloroplast DNA variation of white oaks in Italy. Forest Ecology and Management 156:103-114.

Fini A., F. Ferrini. 2007. Influenza dell'ambiente urbano sulla fisiologia e la sulla crescita degli alberi. Italus Hortus 14(1):9-24.

Fotelli, M., K. Radoglou, and H. Constantinidou. 2005. Water stress responses of seedlings of four Mediterranean oak species. Tree Physiology 20:1065-1075.

Galle, A., P. Haldimann, and U. Feller. 2007. Photosynthetic performance and water relations in young pubescent oak (Quercus pubescens) trees during drought stress and recovery. New Phytologist 174:799810

Gieger, T., and F. Thomas. 2005. Differential response of two CentralEuropean oak species to single and combined stress factors. Trees 19:607-618

Johnson, P.J., S.R. Shifley, and R. Rogers. 2002. Oak-dominated ecosystems. In: The Ecology and Silviculture of Oaks. CABI Publishing, N.Y. pp. 8-53.

Kleinschmit, J. 1993. Intraspecific variation of growth and adaptative traits in European oak species. Annals of Forest Science 50, Suppl. 1. $166 \mathrm{~s}-185 \mathrm{~s}$.

Kremer, A., J. Kleinschmit, J. Cottrell, E.P. Cundall, J.D. Deans, A. Ducousso, A.O. Konig, A.J. Lowe, R.C. Munro, R.J. Petit, and B.R. Stephan. 2002. Is there a correlation between chloroplastic and nuclear divergence, or what are the roles of history and selection on genetic diversity in European oaks. Forest Ecology and Management $156: 75-87$.

Krussman, G. 1986. Manual of Cultivated Broad-Leaved Trees \& Shrubs. Bol. II, Prov-Z. Epp Translator. Timber Press, Portland, OR.

Lo Gullo, M.A., S. Salleo, R. Rosso \& Trifilo. 2003. Drought resistance of 2-year-old saplings of Mediterranean forest trees in the field: relations between water relations, hydraulics and productivity. Plant and Soil 250:259-272. 
Mediavilla, S., and A. Escudero. 2004. Stomatal responses to drought of mature trees and seedlings of two co-occurring Mediterranean oaks. Forest Ecology and Management, 187:281-294.

Nardini, A., M. Lo Gullo, and S. Salleo. 1999. Competitive strategies for water availability in two Mediterranean Quercus species. Plant, Cell and Environment 22:109-116.

Nardini, A., M.A. Lo Gullo, and S. Salleo. 1998. Seasonal changes of root hydraulic conductance (KRL) in four forest trees: an ecological interpretation. Plant Ecology 139:81-90.

Nardini, A., and F. Pitt. 1999. Drought resistance of Quercus pubescens as a function of root hydraulic conductance, xylem embolism and hydraulic architecture. New Phytologist 143:485-493.

Petit, R.J., U.M. Csaikl, S. Bordacs, K. Burg, E. Coart, J. Cottrell, B. Van Dam, J.D. Deans, S. Cumolin-Lapegue, S. Fineschi, R. Finkeldey, A. Gillies, I. Glaz, P.G. Goicoechea, J.S. Jensen, A.O. Konig, A.J. Lowe, S.F. Madsen, G. Matyas, R.C. Munro, M. Olalde, M. Pemonge, F. Popescu, D. Slade, H. Tabbener, D. Taurchini, S.G. M. De Vries, B. Ziegenhagen, and A. Kremer. 2002. Chloroplast DNA variation in European white oak Phylogeography and patterns of diversity based on data from over 2600 populations. Forest Ecology and Management 156:5-26.

Ponton, S., J. Dupouey, N. Breada, and E. Dreyer. 2002. Comparison of water-use efficiency of seedlings from two sympatric oak species: genotype $\mathrm{x}$ environment interactions. Tree Physiology 22: 413-422.

Poyatos, R, P. Llorens, and F. Gallart. 2005. Transpiration of montane Pinus sylvestris L. and Q. pubescens Willd. Forest stands measured with sap flow sensors in NE Spain. Hydrology and Earth System Sciences 9:493-505

Steudle, E., and A. Meshceryakov. 1996. Hydraulic and osmotic properties of oak roots. Journal of Experimental Botany 47:387-401.

Struve, D.K., P. Sternberg, N. Drunasky, K. Bresko, and R. Gonzalez. 2006. Growth and water use characteristics of six eastern North American oak (Quercus) species and the implications of urban forestry. Arboriculture \& Urban Forestry 32:202-213.

Tognetti, R., A. Raschi, C. Beres, A. Fenyvesi, and H. Ridder. 1996. Comparison of sap flow, cavitation and water status of Quercus petraea and Quercus cerris trees with special reference to computer tomography. Plant, Cell and Environment 19:928-938.
Tognetti, R., A. Longobucco, F. Miglietta, and A. Raschi. 1999. Water relations, stomatal response and transpiration of Quercus pubescens trees during summer in a Mediterranean carbon dioxide spring. Tree Physiology 19:261-270.

Valentini, R., G.E. Scarascia Mugnozza, and J. Ehleringer. 1992. Hydrogen and carbon isotope ratios of selected species of a Mediterranean Macchia ecosystems. Functional Ecology 6:627-631.

Zweifel, R., L. Zimmermann, and D.M. Newbery. 2005. Modeling tree water deficit from microclimate: and approach to quantifying drought stress. Tree Physiology 25:147-156.

Zweifel, R., L. Zimmerman, F. Zeugin, and D. Newbery. 2006. Intraannual radial growth and water relations of trees: implications towards a growth mechanism. Journal of Experimental Botany 57:1445-1459.

Daniel K. Struve (corresponding author)

Ohio State University

Department of Horticulture and Crop Science

$241 B$ Howlett Hall 2001 Fyffe Ct.

Columbus, OH 43210, U.S.

Francesco Ferrini

Universitia degli Studi di Firenze

Dipipartimento di Ortoflorofrutticoltura

Firenze, Italy

Alessio Fini

Universitia degli Studi di Firenze

Dipartimento di Ortoflorofrutticoltura

Firenze, Italy

Laura Pennati

Universitia degli Studi di Firenze

Dipartimento di Ortoflorofrutticoltura

Firenze, Italy 
Résumé. Les caractéristiques relatives aux besoins en eau d'une espèce ainsi que ses caractéristiques de croissance sont des aspects importants pour les forestiers urbains. Des semis de trois espèces (en provenance de deux sources) - Quercus cerris L., $Q$. pubescens Willd. et $Q$. robur L. - ont été produits en contenant et soumis à un essai de trois jours quant aux besoins en eau, et ce sous des conditions non limitées d'humidité de sol. Le besoin en eau variait entre les espèces et entre les sources d'une même espèce. Les semis plus gros avaient des besoins en eau plus élevés que les semis plus petits; les semis de $Q$. robur étaient les plus gros $(70,5 \mathrm{~cm})$ et avaient les plus grands besoins en eau $(73,4 \mathrm{~g}$ d'eau), tandis que ceux de $Q$. pubescens et $Q$. cerris étaient plus petits (46 et $45 \mathrm{~cm}$ ) et avaient des besoins moyens en eau de 47,5 et de 44,9 g d'eau respectivement. Les semis de $Q$. pubescens avaient les plus grands besoins en eau par centimètre carré de surface foliaire $(0,11 \mathrm{~g})$; les semis de $Q$. cerris avaient les hauteurs ajustées en eau les plus élevées $(1,4 \mathrm{~g}$ d'eau par centimètre de hauteur). Il n'y avait pas de différence significative dans les besoins en eau entre les différentes sources au sein d'une même espèce. La principale composante d'analyse, faite au moyen de 20 variables, a montré que les sources de semis de $Q$. robur et de $Q$. pubescens étaient groupés alors que les deux sources de $Q$. cerris étaient séparées l'une de l'autre tout comme de celles de $Q$. robur et de $Q$. pubescens. Les grappes reflètent la plus grande distribution proportionnelle de la masse sèche de la croissance des pousses et de la correspondance moindre pour la croissance des racines chez les semis de $Q$. robur et $Q$. pubescens, et ce par rapport aux semis de $Q$. cerris. Les résultats sont mis en relation avec les valeurs relatives chez les pépiniéristes, la valeur potentielle pour les gestionnaires de forêts urbaines et le potentiel de développement de cultivars.

Zusammenfassung. Für einen Forstmann sind die Wasseransprüche und Wachstumseigenschaften einer Baumart wichtig. Es wurden Sämlinge von drei Arten (und zwei Quellen) - Quercus cerris L., Q. pubescens Willd., und $Q$. robur $\mathrm{L}$ - in Containern gezogen und einem dreitägigen Bewässerungsversuch mit unbegrenztem Wasserangebot unterzogen. Der Wasserverbrauch variierte unter den Arten und innerhalb der Art entsprechend der Herkunft. $Q$ robur-Sämlinge waren die größten $(70,5 \mathrm{~cm})$ und hatten auch den Sämling mit dem größten Wasserverbrauch $(73,4 \mathrm{~g})$, während $Q$. pubescens und $Q$. cerris-Sämlinge kürzer (46 und $45 \mathrm{~cm}$ ) waren und entsprechend weniger Wasser verbrauchten (47,5 und 44,9 g). Q. pubescens-Sämlinge hatten den größten Wasserverbrauch pro $\mathrm{cm}^{2}$ Blattfläche $(0,111 \mathrm{~g}), Q$. cerris hatte den höchsten Wasserverbrauch im Höhenwachstum (1,4 g / cm-1 Höhe). Es gab signifikante Unterschiede innerhalb der Art bei den unterschiedlichen Herkünften. Eine grundsätzliche Komponentenanalyse mit 20 Variablen zeigte, dass Sämlinge von $Q$. robur und $Q$. pubescens Quellen Cluster bildeten, während die zwei $Q$. cerris-Quellen separat voneinander und den anderen blieben. Der Cluster-Effekt verdeutlicht die proportional größere Verteilung des Trockengewichts von Triebwachstum und korrespondierend weniger Wurzelwachstum bei $Q$. robur und pubescens Sämlingen als bei $Q$. cerris-Sämlingen. Die Resultate werden in Beziehung gestellt zum relativen Wert der Art für den Baumschulproduzenten und zum potentiellen Wert für urbane Forstwirtschaft und potentielle Kultivar-Entwicklung.

Resumen. Las características del uso del agua por las especies y los hábitos de crecimiento son importantes para los forestales urbanos. Brinzales de tres especies (y dos orígenes)-Quercus cerris L., Q. pubescens Willd., y $Q$. robur L.- crecieron en contenedor y fueron sometidas a un ensayo de uso del agua de tres días bajo condiciones de humedad del suelo no limitantes. El uso del agua varió entre especies y entre orígenes dentro de las especies. Los brinzales más grandes usaron más agua que los más pequeños; los brinzales de $Q$. robur fueron los más altos, $70.5 \mathrm{~cm}$ (27.8 pulg), y tuvieron el uso de agua mayor, $73.4 \mathrm{~g}$ ( $2.5 \mathrm{onz})$, mientras que los brinzales de $Q$. pubescens y $Q$. cerris fueron los más pequeños, 46 y $45 \mathrm{~cm}$ (18.1 y 17.7 pulg), y promediaron 47.5 y $44.9 \mathrm{~g}$ (1.68 y 1.58 onz) de agua, respectivamente. Los brinzales de Quercus pubescens tuvieron el más alto uso del agua cm-2 de área foliar $(0.111 \mathrm{~g}) ; Q$. cerris tuvo el uso de agua más alto (1.4 g de agua cm-1 de altura). Hubo diferencias significativas en uso de agua entre orígenes dentro de las especies. El análisis principal de componentes, usando 20 variables, mostró que los brinzales de $Q$. robur y $Q$. pubescens se agruparon mientras que los brinzales de dos fuentes de $Q$. cerris resultaron separados uno y otro de $Q$. robur y $Q$. pubescens. El análisis de aglomerados reflejó las distribuciones más grandes de proporcionalidad de peso seco a crecimiento de brotes y por tanto menor al crecimiento de raíz de los brinzales de $Q$. robur y $Q$. pubescens, que para $Q$. cerris. Los resultados son comparados al valor relativo de las especies para los viveristas y el valor potencial para los manejadores de bosques urbanos y el potencial para el desarrollo de cultivares. 